\title{
THE NEED FOR SAFETY AND THE DEVELOPMENT OF CONSUMERISM IN POLAND
}

The development of consumerism in Poland falls on the last quarter of the century, the transition from controlled economy to free market economy. Elements of the consumer society, in which durables are becoming less and less important and the skillful manifestation of the social position by purchasing fashionable and, simultaneously, symbolic goods that quickly wear out despite their value is becoming more and more important, have reached us before. The essence of the process is that more and more frequently goods should be replaced by subsequent more updated goods - symbols. The most expensive best-make car has not been a symbol of the status for decades any more but only up till a new stylized model of the same make shows up.

The position in such an altered society regardless of the country where changes take place depends not on the amount of financial resources but the ability to exchange them for goods of the appropriate meaning. Therefore, in the consumer society one of the driving mechanisms is anxiety and fear connected with the lack of appropriate skills to adjust to changeable conditions.

One of the basic human needs is safety and satisfying this need is one of human priorities. However, in the consumer society, such as the Polish one, despite the lack of a direct armed threat and in spite of proper health care and social welfare fear has constantly been fuelled.

Experts collaborating with one another to develop the market are called "market beaters" (Bauman, 2005: 173). Their role, according to the author of the book entitled Europe, unfinished history, consists in formulating hazy and scattered concerns into definite, named needs, and then presenting a current market offer as a proper reply to the demand. The same concerns can be transformed in many ways to make them correspond to various offers - and indeed, they are processed several times. If, for any reason, the offer is withdrawn, connections made before should be cut, and loose ends tied in another knot (ibidem).

Anxiety appears as a driving force of market conditions. It makes the consumer, longing for peace, spend money on the following products to get rid of the feeling that he/she can do nothing to gain inner peace and breathe a sigh of relief as a result of buying.

To such a situation Bauman ascribes the fall of the welfare state idea. "Surely the most significant offer withdrawn nowadays from the 'political market' is the idea of the 'welfare state'. This illogical idea of the consumer market has become the first victim of the state's withdrawal from the responsibility to regulate the sphere of the economic action normatively" (ibidem). 
The consumer market derives its vital power from the same capital of fear that was promised to have been crushed with by the state when it was going to become a welfare state. According to this assumption and for this reason mainly, everything associated directly or indirectly with philosophy and practice of the 'welfare state' is cursed by theoreticians and practitioners of the consumer market. "Success of the welfare state means stagnation in the market or its fall, therefore, the welfare state is the first obstacle market forces have to remove from the way leading to success" (ibidem).

Obviously, it does not mean that every state except for the liberal state is against the free market. The free market will develop in every place where the level of fear may be stimulated and an impression can be made that the market will enable to eradicate all threats. It does not matter if we deal with the liberal state, regime or the so called communist state.

This problem is perceived similarly by Barber. Although - as he remarks - each state which limits the market, may head for transformation to make the market function properly. Due to that the world will unify in the likeness of one market. "Although sociologists of customs and habits will still differentiate between Japanese and American lifestyles, the habit of shopping has the same traits all over the world. Cynics would even say that the true aim of some revolutions that took place some time ago in Europe was not just freedom and the right to vote but well-paid jobs and the right to do shopping. Shopping means consumption and consumption depends on fabricating needs and goods which are included in the specific sector of economy based on the info-entertaining tele-sector" (Barber, 2005: 25). Therefore, what we can deal with are not only transformations of the social systems, but in the most extreme interpretations - unifications of the consumer community.

While the description of the process itself can be treated seriously, it is difficult not to reject the concept of reaching the market that would unify the needs and ways to satisfy them. Globalization, on the one hand, strives for the unification, however automatically the opposition appears.

A significant trace that should be researched is a matter of anxiety and the possibility to trigger it as well as the opportunity or the lack of opportunity to get rid of it. What follows is the driving force in the market which is necessary as it fuels anxiety. Obviously, it is not some unknown force, independent from the human. This force is an individual human decision, used in corporation actions. As Barber claims, "The market as a product of individual decisions or individual actions taken by corporations does not represent collective responsibility. And responsibility itself is a basic duty of citizens and civil institutions" (ibidem). The lack of collective responsibility makes individual decisions fuel the mechanism of collective anxiety.

No reference to something general can cause fear. An uncertain individual that does not have any backup in the community, is exposed to more frequent independent decision making. Nothing determines its rightness and this must lead to anxiety, the feeling of being lost, and transferring this condition to others, especially as fear of others unites the community. This unification, however, is just the unification for the common consumption.

Thus, we can say that the force driving the process of fuelling anxiety is the lack of generally accepted norms. 
"It just happened", Bauman comments on the lack of norms, "that the appearance of the consumer society in the era of flexible modernity undermined credibility and influence of both arguments for inevitability of the social compulsion - in each case in a different way, although for the same reason: more and more visible and progressing process of disassembling a widespread system of the normative control, liberating larger areas of human behaviour from repressive models imposed by the society, supervising and transferring a bigger number of social functions to the world of 'life politics' in individual men and women. In free and privatized conditions focusing on consumers' interests and needs, responsibility for choices, actions taken as a result of them and consequences of these actions are entirely taken by individuals" (Bauman, 2007: 32-33).

We cannot, however, say that the lack of norms or establishing them by an individual again and again must make the individual scare oneself and others, living in a constant calling oneself and others for consumption.

"Pierre Bourdieu indicated two decades ago," continues the author of the book: Chances of ethics in the globalized world, "that the compulsion was actually replaced by the stimulation, power imposing of obligatory behaviour patterns by 'seduction', behaviour supervising by public relations and ads, and the normative control itself by fuelling new needs and desires" (ibidem: 33).

However, if we take into consideration that it is difficult to devise new needs as we always deal with the same needs, we just satisfy them in a different way (we cannot find another need to replace satiation, we just can become saturated with other products), the need for safety seems an interesting means to stimulate consumption.

If we satisfy the need for satiation, it will be difficult to stimulate it further. However, when we make the system aware that tomorrow it may not have anything to eat, it will buy the next product thinking it will feel more confident. Obviously, this product should be stored, etc.

Anxiety can be both the beginning and the end of consumption, without a feeling that something is wrong here.

Felicjan Bylok states that according to John Brewer (Bylok, 2005: 233-423) there are seven traits describing consumption: (1) Products satisfy 'wishes' and not 'needs' i.e. pleasures; (2) Shaping various systems of goods and services symbols allows to influence shaping consumer's needs; (3) Consumer goods function not only as carriers of the meaning but the middlemen of the meaning as well. With the use of them the lifestyle and its demonstration are individualized (it concerns tastes, fashion and lifestyle); (4) The dominance of leisure and consumption over the time of services and production. Consumption and leisure have become the arena of games, creativity and self-realization, self-development, consumer orientation in the area of free time; (5) The development of the 'consumer' category. The consumer - a specific object of actions, identification of individuals by fulfilling particular roles, a causative factor of social changes; (6) Changes for the new system of values, in which consumption has its central place; (7) Institutionalizing of consumption criticism. The result of threats from the mass consumption for the natural and social environment. The mass consumption is introduced as a new 'opium for the masses'.

Many aspects of consumption were contained in the points mentioned above. A significant thing is that along with typical consumption features, its criticism is included 
here as well. According to this, the thesis of consumption comprises its own antithesis at the very beginning. Thus, one of the basic traits of the consumer society is to notice their drawbacks by at least some part of the consumer community. A critical attitude to consumption is its natural consequence, and not a critical attitude towards criticism itself. One may even say that scholars, who are accused of having no programme to overcome difficulties connected with consumption, become an inherent part of the system of consumption.

The problem of consumption itself with its many dimensions, lack of rules and internal contradictions resembles postmodernism. There are many similarities here, one of which is in-depth criticism of both phenomena, and, simultaneously, merging of various discourses concerning these phenomena.

If postmodernism is an ideology of consumption, it becomes clear that criticism of 'consumption critics' can go even further. They may be treated as yielding to the basic principle of consumption. Consumption critics become an inherent part of this anxiety that must be satisfied. They accelerate consumption just like all other marketing activities by its demonization and attributing to it the ability to rule the souls.

Let us just have a look at the following words: "The consumption society", as J. Baudrillard claims, "does not produce its own myths as the society is its own myth for itself. The place of the devil bringing Evil and Affluence (for the soul's price) was taken by Prosperity. Similarly to the fact that the most devilish aspect of the devil has never been his existence but convincing us to believe in him, Prosperity does not exist, either, it is enough to believe its existence to make it an efficient myth" (Baudrillard, 2006: 270). Prosperity as the devil of our times we believe in, which, however, is just a myth, becomes a living myth, revived every time by the act of buying. The consumer comes closer, wants and gets nothing, does not have any satisfaction.

"Consumption is a myth. It means that it is an expression of the contemporary society about itself, using a language it communicates in" (ibidem: 271), the author of Consumer society continues. To a certain degree the only objective reality of consumption is the idea of consumption, reflection and discursive configuration, which - repeated tirelessly, in a colloquial language and an intellectual discourse simultaneously - has become a common-sense category. For Baudrillard the myth of consumption may be perceived as a common-sense approach to reality.

This common-sense image of the myth can obviously enslave. Ritzer, for example, compares consumption to the prison system, described by M. Foucault (Foucault, 1993). Similarly to the fact that there is no overwhelming iron cage but plenty of mini-cages, "Every temple of consumption is a mini-cage, and consumers are enslaved there. By the analogy to Foucault's term of the solitary archipelago, one can state that the new means of consumption is a formed island - a part of a larger archipelago, and the consumer is allowed to move from one island to another one (for example, from one shopping centre to another one), but everywhere he/she is enslaved" (Ritzer, 2001: 308).

In the world the consumer has believed, there is no place for freedom, there is no place for free choices, everything has been subordinated to the enslaving myth - power that exists as an image and has nothing to do with reality but, simultaneously, real power that influences individuals, enslaving them when they still think that they are in- 
fluenced by and subordinated to objective reality. There is no other choice. There is just subordination, becoming similar to other consumers, just the same as we are.

Between the devil and prison the consumer has not been an individual deciding about himself anymore but a scared individual that stands in front of the Satan behind the bars. This picture, which obviously may amuse us, if we treat it seriously, is an introduction to the reality of uncertainty, enslavement and fear. Fear against consumption is the same fear which leads to consumption. When we try to get rid of consumption, we become more sophisticated consumers - such consumers who, by their behaviour, try to show that they are unlike others. The kind of consumption in question is, for example, getting to know works on consumption, which gives a scared consumer the surface impression that he knows what processes he is subjected to and, what is more, that he controls them and can distance himself from them totally. He has been acquainted with it after all. Meanwhile, the teacher and the consumption theoretician gains recognition and wins renown, and, simultaneously, from the person criticizing consumption, through the one that accelerates consumption, he transforms to the manufacturer of consumer goods.

Therefore, we do deal with two coinciding trends or - more exactly - two trends that complete each other. The consumption critic becomes a higher level consumer. His needs are satisfied temporarily only. He can consume knowledge on harmful consequences of consumption and, at the same time, he only consumes this knowledge without satisfying his need.

When we consider consumer's opportunities, particularly in case of a model consumer (i.e. a middle class consumer), it is difficult not to admit that limitless possibilities are not as exciting as it may seem. The consumer cannot feel this satisfaction and when he feels it, he cannot feel it is something extraordinary, on the contrary - he should feel ordinariness as soon as possible since everything that is ordinary, forces us to search every day. And all that is monotonous, may serve as an introduction to the subsequent consumption.

"Getting bored with a product accelerates consumption," claims Tomasz Szlendak. "Getting bored with sex accelerates consumption of sexual boredom 'killers'. Nowadays the sexual sphere is ruled by the same mechanisms which control all culture. Sex is entertainment, it is associated with loafing around, just like shopping. Therefore, sex is treated as materially, rationally, and, at the same time, magically and irrationally as shopping in consumption temples" (Szlendak, 2004: 144).

An example which depicts a situation of the bored consumer, may be widened to any activity. Eating exquisite meals and driving elegant cars can become as boring as sex. It seems that you can escape from boredom unless repeated action are modified or constantly repeated in their new versions. A new element causes excitement and gives the impression of otherness, it, however, becomes boring when we get to know it.

Thus, boredom is a condition which an individual is to avoid, but, on the other hand, the condition he/she must constantly experience. It is also the condition that should be avoided and the condition one ceaselessly has to experience. "The consumption society is also the society to be learnt consumption, social training and introduction into consumption" (Baudrillard, 2006: 94). Ambivalence of getting between satisfaction and its lack is a driving force of consumption. This is why, the consumer must fully get bored 
even if he/she is on the constant move, he is busy or has a feeling of satisfaction, there must be anxiety of fear, i.e. space or emptiness that cannot be filled by anything.

We, obviously, can talk about the attitude of a critical consumer that is supposed to be some prevention from boredom, which is what Felicjan Bylok does. He claims that such an approach deepens knowledge on goods, it is also a larger skepticism towards advertisements, growing demands towards consumer goods as well as increasing awareness on consumer rights (Bylok, 2005: 244). However, isn't it anything else than being trapped by getting even more bored? The consumer starts fighting for his rights when he knows them, he does not want to be manipulated or used, he wants to buy better goods consciously and, as a result, he does not deepen his life attitude but is a creator of his own consumer approach. Boredom is subjected to criticism and, consequently, the critical consumer is busy for a while with consumption, the one that is aware and educated, having an impression of his own value and putting aside the thought that boredom is as present as a moment ago. He receives internal motivation to be an active aware consumer.

In this case we should admit that Baudrillard is right: "Consumption is an active and collective behaviour, a compulsion and an order, morality and an institution. It is the whole system of values along with everything that this term implies, i.e. functions of the group integration and social control" (Baudrillard, 2006: 94). Every consumer is controlled. The critical consumer's situation does not differ from any other at all since it is hard to find another way in this discourse, it is even difficult to think differently.

The consumer society, as Juliet B. Scholar notices, is based on the constant increase in consumer expenses, and this increase is essential for the economic operation of the system. Moreover, culture, ideology and morality develop according to this economic system. Insatiability becomes a common norm. Social and political stability remain dependent on providing consumer goods (Scholar, 1999: 8). All other walks of life in the consumer society depend on economy. It, however, may be efficient only when everyone will be simultaneously bored with the surrounding world and prone to a constant effort at work, the effort for which they will receive money for shopping and the effort concerning looking for goods. And all this effort is just to make boredom less severe, to feel it shorter and not to realize that we are on the verge of depression.

Indeed, nothing is able to eliminate boredom. The attempts have ended up with failure for a long time. Boredom can be found where nothing goes on and everything is on the constant move. Even a shock has not been able to attract our attention for a long time and put boredom aside: "Sensitivity of the sixties," Daniel Bell claims, "is important as a proof that esthetics of the shock and sensation became trivial and boring; it became the property of cultural masses and is one more symbol of capitalism cultural contradictions" (Bell, 1998: 181). The shock, which as a rule cannot become boring since it is something unusual and means overcoming all the barriers and crossing borders, appears in such a great amount that it does not absorb, it does not even surprise. It is something regular and overused. Everyday life is not shocking, it is boring.

If we do not deal with fear in the consumer society, we cope with boredom. What should one be afraid of? That a traditional Polish dinner will take place without 'a marvelous bottle of Coca Cola' and, simultaneously, there is nothing else like getting bored with this product just like you can get bored with every week change of juice for dinner to another similar one? 
The Polish consumer just like any other is suspended between boredom. We have to emphasize that in every Pole's life there is also real fear. It is caused by the possibility of dying in the accident or as a result of disease, getting dismissed, losing home because of being unable to pay off the loan and similar problems.

Thus, there is fear of living threats but there are also other fears, such as no ability to adapt, no ability to match clothes and accessories, to buy a prestigious product but not a pretentious one, or to spend time in a cheerful but not funny way, etc.

In case of these threats connected with social relations (as we deal with them in case of consumption), we cannot say they are less important. These anxieties can be the reason for larger social anxieties than life or health threats associated with human biology. Threats that cannot be eliminated are something else than threats that can be eradicated by means of purchasing appropriate goods. Unless there are too big divisions connected with the access to resources in the society, it is not such a great problem. However, when differences among salaries received for work are getting bigger and bigger, as in Poland, one should think if finding other means than consumer ones and providing a place in the society is not a priority of individuals belonging to such a society. And this may cause not a destabilization of the consumer society system but its transformation and therefore, the feeling of danger.

However, consumption itself will never be able to give the feeling of safety as constant fear and ceaseless boredom must lead to a defensive reaction and looking for other solutions than the ones that have not given any long-lasting effects so far.

\title{
Bibliography
}

Barber B. R. (2005), Dzihad kontra McŚwiat, Warszawa.

Baudrillard J. (2006), Społeczeństwo konsumpcyjne. Jego mity i struktury, Warszawa.

Bauman Z. (2005), Europa. Niedokończona przygoda, Kraków.

Bauman Z. (2007), Szanse etyki w zglobalizowanym świecie, Kraków.

Bell D. (1998), Kulturowe sprzeczności kapitalizmu, Warszawa.

Bylok F. (2005), Model społeczeństwa konsumpcyjnego i jego zastosowanie na poczqtku XXI wieku, in: Konsumpcja - istotny wymiar globalizacji kulturowej, (eds.) A. Jawłowska, M. Kempny, Warszawa.

Foucault M. (1993), Nadzorować i karać. Narodziny więzienia, Alathea-Spacja, Warszawa.

Ritzer G. (2001), Magiczny świat konsumpcji, Warszawa.

Scholar J. B. (1999), The Overspent American. When We Want We Don't Need, New York.

Szlendak T. (2004), Supermarketyzacja. Religia i obyczaje seksualne młodzieży w kulturze konsumpcyjnej, Wrocław.

\begin{abstract}
The development of consumerism in Poland falls on the last quarter of the century, the transition from controlled economy to free market economy. Elements of the consumer society, in which durables are becoming less and less important and the skillful manifestation of the social
\end{abstract}


position by purchasing fashionable and, simultaneously, symbolic goods that quickly wear out despite their value is becoming more and more important, have reached us before. The essence of the process is that more and more frequently goods should be replaced by subsequent more updated goods-symbols. The position in such an altered society regardless of the country where changes take place depends not on the amount of financial resources but the ability to exchange them for goods of the appropriate meaning. Therefore, in the consumer society one of the driving mechanisms is anxiety and fear connected with the lack of appropriate skills to adjust to changeable conditions.

\section{POTRZEBA BEZPIECZEŃSTWA A ROZWÓJ KONSUMERYZMU W POLSCE}

\section{STRESZCZENIE}

Rozwój konsumeryzmu w Polsce to okres ostatniego ćwierćwiecza, przejścia od gospodarki sterowanej do gospodarki wolnorynkowej. Oczywiście już wcześniej docierały do nas elementy społeczeństwa konsumpcyjnego, w którym coraz mniej ważne staje się posiadanie trwałych dóbr a coraz ważniejsze staje się umiejętne manifestowanie pozycji społecznej przez zakup modnych i zarazem obdarzonych dużym ładunkiem symbolicznym dóbr, które pomimo swej wartości szybko zużywają się. Istotą procesu jest to, że coraz częściej dobra trzeba zastępować kolejnymi bardziej aktualnymi dobrami-symbolami. Pozycja w takim odmienionym społeczeństwie tak naprawdę niezależnie od kraju w którym się odbywają zmiany zależy nie tyle od ilości zgromadzonych środków finansowych co od umiejętności zamiany ich na dobra o odpowiednim znaczeniu. Dlatego w społeczeństwie konsumpcyjnym jednym z mechanizmów napędowych staje się niepokój a właściwie strach związany z brakiem odpowiednich umiejętności dostosowania się do zmiennych warunków. 